Article

\title{
Influence of Chitin Nanocrystals on the Crystallinity and Mechanical Properties of Poly(hydroxybutyrate) Biopolymer
}

\author{
Marta Zaccone ${ }^{1, *(D)}$, Mitul Kumar Patel ${ }^{2}$, Laurens De Brauwer ${ }^{3}$, Rakesh Nair ${ }^{3}$, Maria Luana Montalbano ${ }^{1}$, \\ Marco Monti ${ }^{1}$ (D) and Kristiina Oksman $2,4,5, *$ (D)
}

check for

updates

Citation: Zaccone, M.; Patel, M.K.;

De Brauwer, L.; Nair, R.; Montalbano,

M.L.; Monti, M.; Oksman, K.

Influence of Chitin Nanocrystals on the Crystallinity and Mechanical

Properties of Poly(hydroxybutyrate)

Biopolymer. Polymers 2022, 14, 562.

https://doi.org/10.3390/

polym14030562

Academic Editors: Sergio

Torres-Giner and Maria Vargas

Received: 27 December 2021

Accepted: 26 January 2022

Published: 29 January 2022

Publisher's Note: MDPI stays neutral with regard to jurisdictional claims in published maps and institutional affiliations.

Copyright: (C) 2022 by the authors. Licensee MDPI, Basel, Switzerland. This article is an open access article distributed under the terms and conditions of the Creative Commons Attribution (CC BY) license (https:// creativecommons.org/licenses/by/ $4.0 /$ )
1 Proplast, Via Roberto di Ferro 86, 15122 Alessandria, Italy; luana.montalbano@proplast.it (M.L.M.); marco.monti@proplast.it (M.M.)

2 Division of Materials Science, Department on Engineering Sciences and Mathematics, Luleå University of Technology, SE 97187 Luleå, Sweden; mitul.kumar.patel@ltu.se

3 Bio Base Europe Pilot Plant (BBEPP), Rodenhuizekaai 1, 9042 Gent, Belgium; laurens.de.brauwer@bbeu.org (L.D.B.); rakesh.nair@bbeu.org (R.N.)

4 Mechanical \& Industrial Engineering, University of Toronto, Toronto, ON M5S 3BS, Canada

5 Wallenberg Wood Science Center (WWSC), Luleå University of Technology, SE 97187 Luleå, Sweden

* Correspondence: marta.zaccone@proplast.it (M.Z.); kristiina.oksman@ltu.se (K.O.)

\begin{abstract}
This study focuses on the use of pilot-scale produced polyhydroxy butyrate (PHB) biopolymer and chitin nanocrystals (ChNCs) in two different concentrated (1 and $5 \mathrm{wt} . \%)$ nanocomposites. The nanocomposites were compounded using a twin-screw extruder and calendered into sheets. The crystallization was studied using polarized optical microscopy and differential scanning calorimetry, the thermal properties were studied using thermogravimetric analysis, the viscosity was studied using a shear rheometer, the mechanical properties were studied using conventional tensile testing, and the morphology of the prepared material was studied using optical microscopy and scanning electron microscopy. The results showed that the addition of ChNCs significantly affected the crystallization of PHB, resulting in slower crystallization, lower overall crystallinity, and smaller crystal size. Furthermore, the addition of $\mathrm{ChNCs}$ resulted in increased viscosity in the final formulations. The calendering process resulted in slightly aligned sheets and the nanocomposites with $5 \mathrm{wt} . \%$ ChNCs evaluated along the machine direction showed the highest mechanical properties, the strength increased from 24 to $33 \mathrm{MPa}$, while the transversal direction with lower initial strength at $14 \mathrm{MPa}$ was improved to $21 \mathrm{MPa}$.
\end{abstract}

Keywords: biopolymer; polyhydroxy butyrate; chitin nanocrystals; nanocomposites; crystallinity; mechanical properties

\section{Introduction}

In recent years, bio-based and biodegradable polymers, such as polylactic acid (PLA), polycaprolactone (PCL), and thermoplastic starch-based polymers (TPS), have emerged as promising alternatives to fossil-based materials because of their many advantages, such as biodegradability, environmental compatibility, and their renewable origin [1,2]. In addition to these biopolymers, polyhydroxyalkanoates (PHAs) also possess these properties [3-6]. These bio-polyesters are synthesized by bacterial species and have shown promise in many applications, such as biomedical and pharmaceutical, agricultural, single-use products, and packaging $[4,7,8]$. Among the family of PHAs, poly(3-hydroxybutyrate) (PHB) is one of the most extensively studied because of its physical and mechanical properties, which are comparable to those of petrochemical-derived polymers like polypropylene (PP) [9-13]. Indeed, PHB exhibits good mechanical and oxygen barrier properties. Moreover, it is stable under normal usage conditions but undergoes rapid biodegradation under composting conditions [14]. Nevertheless, PHB is susceptible to thermal degradation, has a narrow 
processing window, and shows severe post-process embrittlement, which reduces the applicability of this biopolymer [3,10,15-17].

Several solutions have been presented to overcome these shortcomings [18]. One possibility is the synthesis of copolymers like poly hydroxybutyrate-co-valerate (PHBV). Indeed, a stiffer product with a higher $\mathrm{HB}$ content or a tougher material with a higher $\mathrm{HV}$ content can be obtained by adjusting the hydroxybutyrate/hydroxyvalerate $(\mathrm{HB} / \mathrm{HV})$ ratio. Nonetheless, this approach is not cost-effective, and the presence of the copolymer affects the crystallization kinetics of PHB, resulting in longer processing cycle times [19]. Another alternative is to reduce the brittleness of PHB by performing annealing, which substantially improves the processability and mechanical stability of the polymer [20], but this also leads to longer processing cycles. Finally, a third possibility is the formulation of nanocomposites, as nanosized additives may enhance the final material properties [21,22]. Many studies have focused on PHB-or PHBV/clay-based nanocomposites [1,23-27]. Similarly, cellulose nanowhiskers (CNWs) are of high interest for biopolymers because they can be obtained from renewable sources and can improve the mechanical properties of the final nanocomposites [28]. Another way to improve the mechanical properties of biopolymers is to alter the molecular orientation of the polymer. Oriented polymer films and tapes can be obtained by melt-drawing processes, such as film (sheet) calendering and blow molding. During melt drawing, the polymer molecules are stretched at the exit of the extruder die and are oriented along the flow direction.

Chitin is an abundant natural polymer that has attracted considerable attention from the scientific community [29-31]. Chitin can be extracted from the exoskeleton of crustaceans, such as crabs and shrimp, and is used in a variety of applications owing to its biodegradability and biocompatibility [32,33]. Moreover, owing to the hierarchical structure of chitin, chitin nanofibers (ChNFs) and nanocrystals (ChNCs) can be extracted from chitin in a top-down manner. These chitin nanomaterials have a high aspect ratio, high specific surface area, and impressive mechanical properties [30,31,34-36]. There are several reports on the lab-scale preparation of ChNCs from different raw material sources, such as squid pen [36], crab shells [37,38], and shrimp shells [39,40], using conventional hydrolysis in $\mathrm{HCl}$ solution. The isolated nanocrystals had aspect ratios of 10-55 and have been studied as nanocomposite reinforcement materials. Hydrolysis with a strong acid $\left(\mathrm{H}_{2} \mathrm{SO}_{4}\right)$ for $\mathrm{ChNC}$ production has only been reported a few times [41,42]. Furthermore, to the best of our knowledge, the large-scale production of $\mathrm{ChNC}$ s has not been explored.

Several papers have been published on the use of chitin nanomaterials in biopolymer nanocomposites [31,32,43-47]. Li et al. [31] studied the nucleation ability of ChNCs on PHBs. They used ChNCs with and without surface treatment and found that chitin nanocrystals without any modification showed good nucleation ability. Singh et al. [45] studied PLA-ChNC nanocomposites and showed that even a small amount of ChNCs increased the crystallization rate, barrier performance, and hydrolytic degradation rate of PLA. Furthermore, Scaffaro et al. discussed the preparation and use of ChNCs in combination with cellulose nanocrystals in the PLA matrix and presented many studies on cellulose nanocomposites in a review article [43].

However, to the best of our knowledge, only one study has been published on $\mathrm{ChNC}$ nanocomposites with PHB as the matrix. In this study, we investigated the feasibility of pilot-scale produced PHB and ChNCs for the preparation of nanocomposites using melt extrusion and sheet calendering under industrially feasible processing conditions. We studied how the addition of ChNCs affected the crystallization behavior, thermal, rheological, and mechanical properties of PHB.

\section{Materials and Methods}

\subsection{Production of $P H B$}

PHB was produced via fed-batch fermentation of Paraburkholderia sacchari at $29{ }^{\circ} \mathrm{C}$ in a $1500 \mathrm{~L}$ bioreactor according to the method described by Kim et al. [48] with some modifications. Instead of ammonium limitation, as proposed by Kim et al., phosphate limitation was used for PHB production. A total of $1 \mathrm{~mL}$ of P. sacchari culture was thawed 
from the working glycerol stock and inoculated into a $500 \mathrm{~mL}$ sterile mineral medium flask. The shake flask was incubated for $20 \mathrm{~h}$ at $29^{\circ} \mathrm{C}$ and $200 \mathrm{rpm}$, after which the bacteria were inoculated into the bioreactor for growth. The organism was grown in a mineral medium containing glucose, and automated fed-batch culture fermentation was carried out with the use of concentrated glucose shots $(600 \mathrm{~g} / \mathrm{L})$ when the $\mathrm{pO}_{2}$ exceeded $20 \%$ of the set value, as shown in Figure S1 (Supplementary Information).

The glucose concentration of the culture broth was maintained at $10-20 \mathrm{~g} / \mathrm{L}$ based on the $\mathrm{pO}_{2}$ value. The final cell concentration, $\mathrm{PHB}$ concentration, and $\mathrm{PHB}$ productivity increased with increasing cell concentrations and the maximum PHB content $(79 \mathrm{~g} / \mathrm{L})$ and total cell dry weight $(111 \mathrm{~g} / \mathrm{L})$ were obtained at the end of the fermentation process. The maximum PHB content, amounting to $74 \%$ of the dry cell weight, and a productivity of $1.6 \mathrm{~g} / \mathrm{L} \cdot \mathrm{h}$ at a yield of $0.2 \mathrm{~kg} \mathrm{PHB} / \mathrm{kg}$ glucose was achieved at the end of fermentation (Figure S2 in the Supplementary Information).

The biomass at the end of the fermentation process was harvested and processed to purify the intracellular PHB. The biomass first underwent cell lysis under high-pressure homogenization, followed by enzymatic hydrolysis of the cellular material, which resulted in the recovery of intact PHB granules. After washing with water to remove traces of salts and contaminants, $\mathrm{PHB}$ was recovered and dried in a vacuum tray. Based on thermogravimetric analysis (TGA), the PHB had a recovery yield of $90 \%$ with a purity exceeding $95 \%$. The biopolymer was stored at $4{ }^{\circ} \mathrm{C}$ until use.

\subsection{Production of ChNCs}

ChNCs were produced by diluting chitin powder from shrimp shells with an average molecular weight of $203 \mathrm{~g} / \mathrm{mol}$ (Glentham Life Sciences Ltd., Corsham, UK) in 35 wt.\% $\mathrm{H}_{2} \mathrm{SO}_{4}$ (Brenntag NV, Deerlijk, Belgium) for $2 \mathrm{~h}$ at $60^{\circ} \mathrm{C}$ in a Pfaudler AE 400 glass-lined reactor (Thaletec $\mathrm{GmbH}$, Thale, Germany). The liquid was neutralized with $30 \% \mathrm{NaOH}$ and subsequently diafiltered with $0.01 v / v \%$ acetic acid (Brenntag NV, Deerlijk, Belgium) to reach a conductivity of $130 \mu \mathrm{S} / \mathrm{cm}$. Unhydrolyzed chitin was sedimented on a Clara 20 discstack centrifuge (Alfa Laval, Lund, Sweden), and the ChNC-containing supernatant was concentrated using a Carl Canzler Wiped Film evaporator (Quadrant EPP, Tielt Belgium). The concentrate was freeze-dried to obtain a dry, stable product. The process scheme to produce $\mathrm{ChNCs}$ is shown in Figure S3 in the Supplementary Information. The ChNCs were stored at $4{ }^{\circ} \mathrm{C}$ until mixing. About $1.4 \mathrm{~kg}$ of $\mathrm{ChNCs}$ was produced, with a process yield of approximately $34 \mathrm{wt} . \%$.

\subsection{Compounding and Sheet Calendering}

PHB-ChNC nanocomposites were prepared in a co-rotating twin-screw extruder (Leistritz 27E, Nuremberg, Germany), with a $27 \mathrm{~mm}$ screw diameter and a length-todiameter ratio $\mathrm{L} / \mathrm{D}$ of 40 . The screw speed was maintained at $300 \mathrm{rpm}$ for all materials, and the temperature profile was set at $165-175^{\circ} \mathrm{C}$, with the temperature being the highest at the die. Vacuum venting was used to remove air and moisture. The freeze-dried $\mathrm{ChNC}$ powder was fed into the melt PHB using a gravimetric side feeder (Brabender, Duisburg, Germany). Nanocomposites with two different $\mathrm{ChNC}$ contents ( 1 and $5 \mathrm{wt} . \%$ ) were prepared. Figure 1 shows the screw profile and process layout.

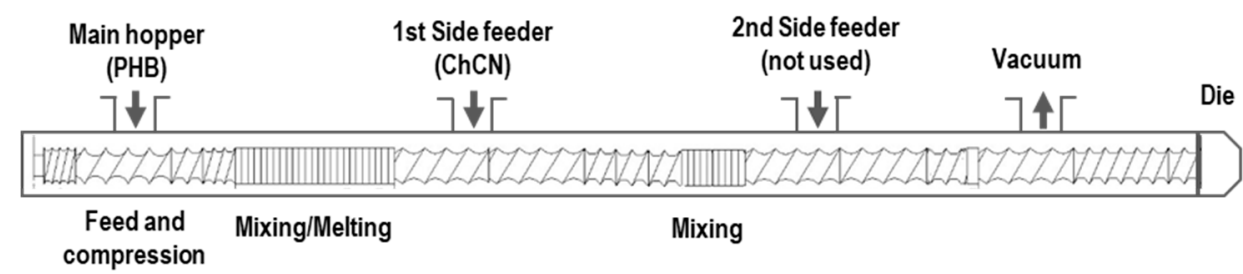

Figure 1. The layout of the twin-screw extruder and its screw design. 
The obtained nanocomposites were extruded into sheets using a single-screw extruder (BGplast SD30, B.G. Plast Impianti SRL, Marnate, Italy) equipped with a flat die (width $200 \mathrm{~mm}$ ) and a calendering system (Dr. Collins CR136/350, Collin Lab and pilot solutions, Maitenbeth, Germany). The prepared compounds were dried before extrusion at $80{ }^{\circ} \mathrm{C}$ for $6 \mathrm{~h}$. The extruded sheets were approximately $500 \mu \mathrm{m}$ thick. The temperature profile was set at $180-190{ }^{\circ} \mathrm{C}$. The temperature of the rolls was set at $30^{\circ} \mathrm{C}$, and the speed was $0.8 \mathrm{~mm} / \mathrm{min}$. Figure 2 shows the used process layout and calendered sheets of PHB nanocomposite.

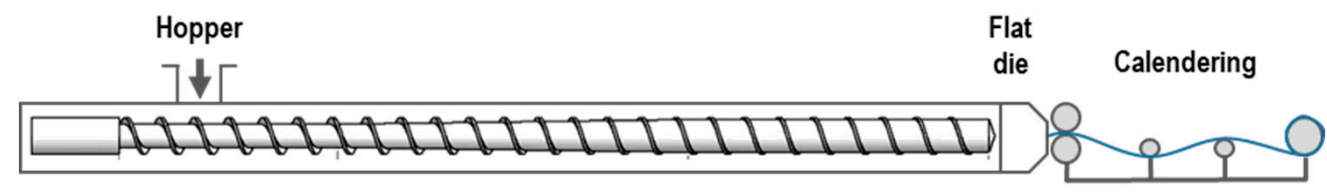

(a)

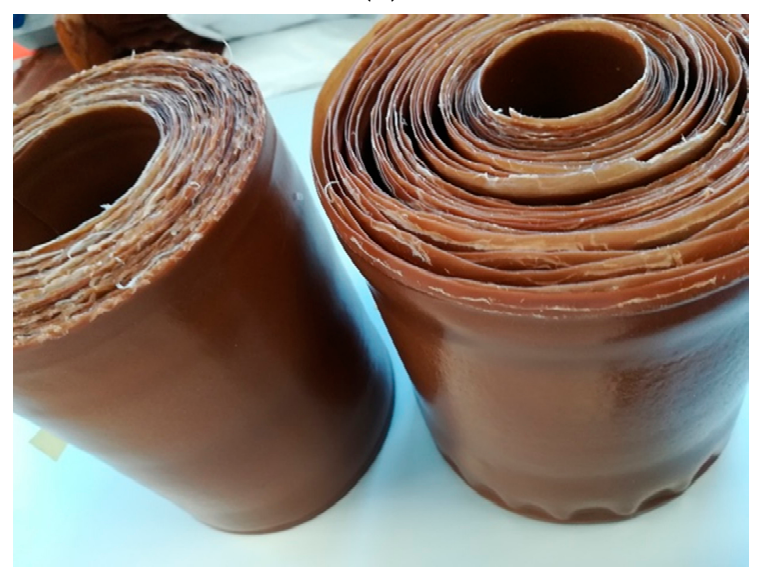

(b)

Figure 2. (a) Film extrusion and calendering process layout and (b) calendered sheets.

\subsection{Characterization}

The morphology of the ChNCs before and after freeze-drying was studied using an optical microscope (Nikon Eclipse LV100 Pol; Bergman Labora AB, Danderyd, Sweden). The $\mathrm{ChNC}$ dispersion was diluted in distilled water to a concentration of $0.1 \mathrm{wt}$. $\%$, followed by magnetic stirring for $2 \mathrm{~h}$ before optical microscopy. In addition, a flow birefringence study was performed to evaluate the quality of the nanocrystals and the effect of freezedrying on the dispersion of the nanocrystals. The diluted dispersions $(0.5 \mathrm{wt} \%$ ) were placed between cross-polarized filters and photographed.

The thermal properties of the prepared $\mathrm{PHB}, \mathrm{ChNCs}$, and nanocomposites were studied by TGA (Q500 TA Instruments, New Castle, DE, USA). TGA was performed in a nitrogen atmosphere at a heating rate of $10{ }^{\circ} \mathrm{C} / \mathrm{min}$ (gas flow rate of $60 \mathrm{~mL} / \mathrm{min}$ ) at $50-800{ }^{\circ} \mathrm{C}$.

The crystallization rate and morphology of neat $\mathrm{PHB}$ and the nanocomposites were studied using polarized optical microscopy (POM, Nikon Eclipse LV100 Pol, Bergman Labora AB, Danderyd, Sweden) equipped with a Linkam THM600 (Tadworth, UK) hot stage and a charge-coupled device camera. PHB was melted between two glass covers at $200{ }^{\circ} \mathrm{C}$ and cooled to room temperature, and crystallization and crystal nucleation were recorded.

Differential scanning calorimetry (DSC) was performed on a Q800 instrument (TA Instruments, New Castle, DE, USA). Approx. $5.5 \mathrm{~g}$ of each sample was used for DSC. The first heating scan was performed to eliminate the thermal history of the tested materials. A 
cooling scan from 210 to $-10^{\circ} \mathrm{C}$ and a second heating scan from -10 to $210{ }^{\circ} \mathrm{C}$, both at $10{ }^{\circ} \mathrm{C} / \mathrm{min}$ rate. The degree of crystallinity was calculated according to Equation (1):

$$
\mathrm{X}_{\mathrm{c}}[\%]=\frac{\left(\Delta \mathrm{H}_{\mathrm{m}}-\Delta \mathrm{H}_{\mathrm{cc}}\right)}{\left(\frac{100-\mathrm{wt} . \%}{100}\right)} \times \frac{100}{\Delta \mathrm{H}_{0}}
$$

where $\mathrm{X}_{\mathrm{c}}$ is the crystalline fraction of the matrix, $\Delta \mathrm{H}_{\mathrm{m}}$ is the melting enthalpy $(\mathrm{J} / \mathrm{g}), \Delta \mathrm{H}_{\mathrm{cc}}$ is the cold crystallization enthalpy $(\mathrm{J} / \mathrm{g}), \mathrm{wt} . \%$ is the $\mathrm{ChNC}$ content by weight, and $\Delta \mathrm{H}_{0}$ is the theoretical crystallization enthalpy of $100 \%$ crystalline PHB. In this calculation, $146 \mathrm{~J} / \mathrm{g}$ was used as the value of $\Delta \mathrm{H}_{0}[49]$.

The mechanical properties were studied using a conventional tensile tester (Zwick Roell Z010 model, Ulm, Germany), and the test was performed according to the UNI EN ISO 527-3 standard. The test was performed in the machine and transfer direction of the calendered sheets (MD and TD). The load cell had a maximum capacity of $10 \mathrm{kN}$. The samples (Type 2, according to the standard) had a rectangular shape, with a total length of over $150 \mathrm{~mm}$, a width of $25 \mathrm{~mm}$, and a thickness of $500 \mu \mathrm{m}$. The crosshead speed was $5 \mathrm{~mm} / \mathrm{min}$ and the applied preload was $2 \mathrm{MPa}$. The strain was calculated by dividing the change in length by the initial length of the sample $(\varepsilon=\Delta \mathrm{L} / \mathrm{L})$.

Rheological characterization was performed in a nitrogen atmosphere using a straincontrolled rotational rheometer (Rheometric Scientific ARES model 2KFRT, TA Instruments, New Castle, DE, USA) with a parallel-plate geometry ( $25 \mathrm{~mm}$ diameter). The purpose of rheological characterization was to understand how the presence of ChNCs affects the rheological behavior of neat PHB. Test specimens were cut from extruded sheets $(500 \mu \mathrm{m}$ thickness). Frequency sweep tests were performed in the $0.1-100 \mathrm{rad} / \mathrm{s}$ frequency range, with a fixed strain of $10 \%$. The test temperature was set at $190{ }^{\circ} \mathrm{C}$.

The morphologies of neat PHB and its nanocomposites were investigated using optical microscopy (OM) and scanning electron microscopy (SEM). OM was performed using a Nikon Eclipse LV100N Pol (Bergman Labora AB, Danderyd, Sweden) and SEM was performed using a JEOL JSM-6460LV (JEOL, Tokyo, Japan). The specimens were cryofractured in liquid nitrogen and coated with a thin layer $(13 \mathrm{~nm})$ of platinum before observation using an EM ACE200 (Leica vacuum coater, Wetzlar, Germany).

\section{Results}

Figure 3 shows the microstructure and birefringence of ChNCs in water dispersions before and after freeze-drying. In the micrograph of never-dried ChNCs, no ChNCs can be seen, indicating successful isolation of chitin into the nanocrystals, see Figure 3a. This is an expected result because the size of the crystals is below the OM resolution limit. In addition, the produced ChNCs exhibited a typical birefringence pattern between the crosspolarized filters, as shown in Figure 3b, because of the chiral nematic liquid crystalline phase in equilibrium with the isotropic phase. Furthermore, the AFM height image in Figure S4 (Supplementary Information) confirms the presence of nanocrystals before the freeze-drying step. Figure $3 c$ shows freeze-dried ChNCs redispersed in water, and the micrograph shows that freeze-drying results in micrometer-sized flake-like particles and loss of birefringence, as shown in Figure $3 \mathrm{~d}$. These results show that the drying step makes it more difficult for $\mathrm{ChNC}$ s to be redispersed in water by forming irreversible strong hydrogen bonds, resulting in agglomeration and loss of birefringence. 
(a)

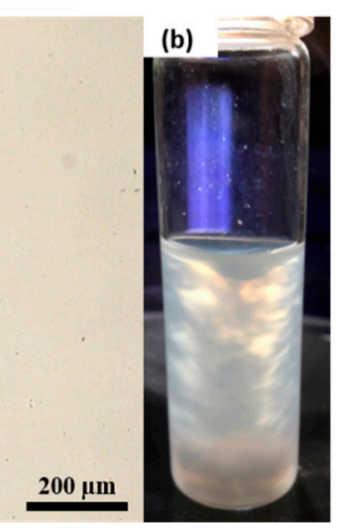

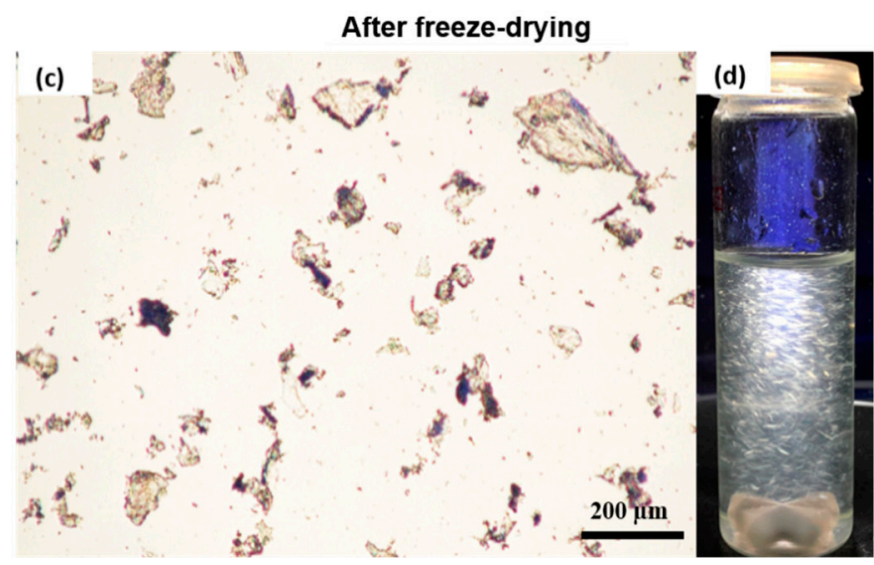

Figure 3. Optical micrographs of ChNCs (a) before and (c) after freeze-drying steps and the birefringence of ChNCs in water suspensions (b) before and (d) after freeze-drying with similar concentrations.

Figure 4 shows the TGA results of the ChNCs, neat PHB, and their nanocomposites. In the case of $\mathrm{ChNCs}$, the first weight loss was obtained at $40-100{ }^{\circ} \mathrm{C}$, which is attributed to the presence of residual humidity. The main weight loss was observed in the $250-400{ }^{\circ} \mathrm{C}$ range, which corresponds to the thermal decomposition of the polysaccharide structure [50]. The final residue of the $\mathrm{ChNC}$ at $800{ }^{\circ} \mathrm{C}$ was approximately $25 \mathrm{wt} . \%$, owing to the presence of sulfate groups on the surface of the ChNCs, which were introduced during acid hydrolysis and could act as a flame retardant, as reported by Roman and Winter for cellulose nanocrystals [51]. Neat PHB and both nanocomposites showed one main thermal degradation step at approximately $275^{\circ} \mathrm{C}$. This value corresponds to the Ton-set of the materials, which indicates the temperature at which the polymer exhibits a weight loss of 95 wt.\% of its initial weight. No differences were observed between neat PHB and the produced nanocomposites with 1 and $5 \mathrm{wt}$ \% ChNCs, except for the presence of a second small shoulder at approximately $350{ }^{\circ} \mathrm{C}$, which is attributable to the presence of ChNCs. The increasing amount of $\mathrm{ChNCs}$ in the matrix corresponds to the increasing height of the second peak.

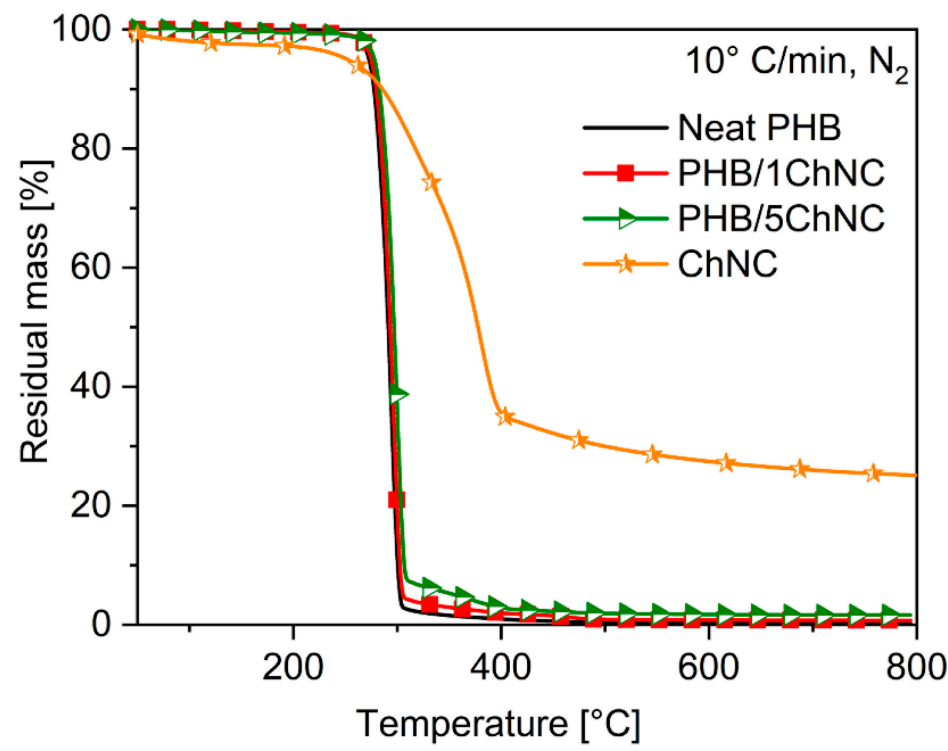

Figure 4. Weight loss as a function of temperature for ChNCs, $\mathrm{PHB}$, and the ChNC-nanocomposites of PHB in a nitrogen atmosphere.

Figure 5 shows the crystallization of $\mathrm{PHB}$ and its $\mathrm{ChNC}$ nanocomposites at (a) $80{ }^{\circ} \mathrm{C}$ after $1 \mathrm{~min}$ and (b) $60^{\circ} \mathrm{C}$ after $2 \mathrm{~min}$. From Figure 5(a1), it is evident that neat PHB had al- 
ready started to crystallize and formed spherulites at $80^{\circ} \mathrm{C}$ during the first minute, whereas the nanocomposites showed no spherulite development at this temperature during the first minute, shown in Figure 5(a2,a3). This indicates that PHB has a higher crystallization rate than the ChNCs. Figure 5(b1-b3) was taken at a lower temperature, $60^{\circ} \mathrm{C}$, and after 2 min, neat PHB and both nanocomposites showed spherulite formation, as shown in Figure 5(b1-b3). Larger spherulites in the form of helical strands radiating from a nucleation point were observed for neat PHB. On the other hand, several smaller spherulites were observed for $\mathrm{PHB} / 1 \mathrm{ChNC}$ and $\mathrm{PHB} / 5 \mathrm{ChNC}$, with the size of the spherulites decreasing as the quantity of ChNCs in the nanocomposites increased. This phenomenon is attributable to the higher number of nucleation sites provided by ChNCs, leading to a larger number of spherulites, which in turn limits the ability of the spherulites to grow in size [52]. Furthermore, spherulites could not form in specific areas of nanocomposites, resulting in voids. This phenomenon is caused by a reduction in polymer availability in the particular area owing to the presence of agglomerated ChNCs. PHB/5ChNC exhibited the largest number of voids.
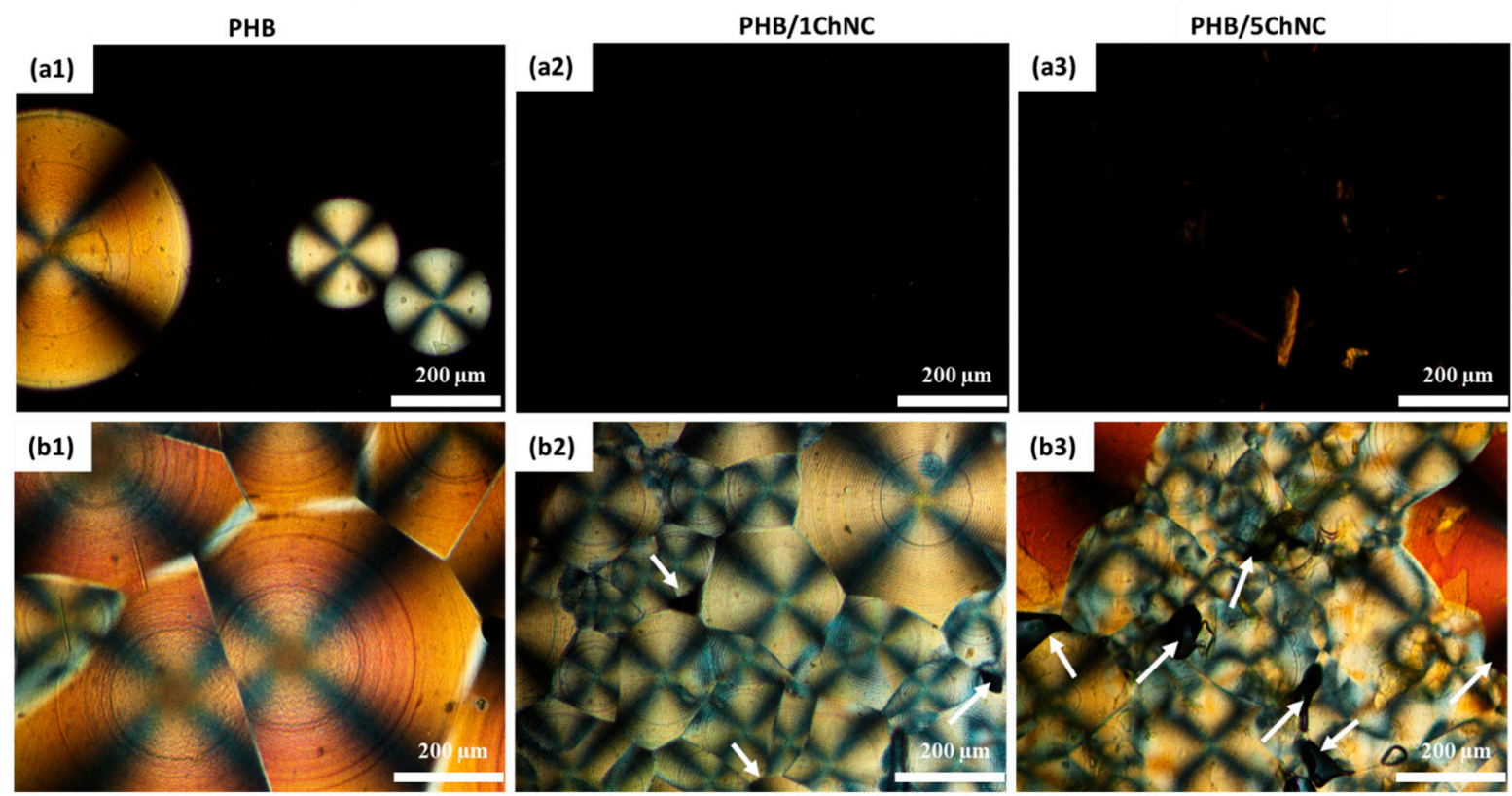

Figure 5. Polarized optical micrographs of $\mathrm{PHB}, \mathrm{PHB} / 1 \mathrm{ChNC}$, and $\mathrm{PHB} / 5 \mathrm{ChNC}$ at $80^{\circ} \mathrm{C}$ for $1 \mathrm{~min}$ are shown in (a1-a3), respectively and at $60^{\circ} \mathrm{C}$ for $2 \mathrm{~min}$ are shown in (b1-b3), respectively.

Table 1 shows the DSC results and degree of crystallinity of neat PHB and the produced nanocomposites. Based on the results, it is evident that the degree of crystallinity was lower in the presence of ChNCs. Figure 6a shows the DSC results pertaining to the cooling cycles of neat PHB and its nanocomposites. The graph of the cooling cycle and the crystallization temperatures (Tc) values in Table 1 show that the Tc of neat PHB is $66^{\circ} \mathrm{C}$, and the Tc shifts to lower temperatures on increasing the $\mathrm{ChNC}$ content $\left(\mathrm{PHB} / 5 \mathrm{ChNC}\right.$ has a Tc of $49^{\circ} \mathrm{C}$ ). Figure $6 \mathrm{~b}$, which relates to the second heating cycle, shows that the cold crystallization peak of the nanocomposites is at approximately $42{ }^{\circ} \mathrm{C}$ (Tcc); this peak is not observed for PHB. Cold crystallization is typical in polymers with low crystallinity and is related to the difficulty of the polymer chains to crystallize during the cooling phase from the melt. Moreover, as in the first heating cycle, a lower degree of crystallinity was observed in the presence of ChNCs. These results, together with the lower Tc shown in Figure $6 \mathrm{~b}$ and discussed previously, indicate that the presence of ChNCs hinders the crystallization process both in terms of the crystallization rate and degree of crystallinity. These results agree with the POM study. The reduced crystallinity of the nanocomposites may be attributed to the hindered motion of polymer segments caused by the presence of ChNCs in 
the matrix. Notably, the cold crystallization peak appeared only after a phase of controlled cooling at $10{ }^{\circ} \mathrm{C} / \mathrm{min}$, as described in the DSC analysis. This peak is not visible during the first heating cycle, which means that the cooling phase during sheet extrusion was slower and allowed full crystallization of the nanocomposites from the melt. According to the literature [53], in some cases, the presence of ChNCs may decrease the crystallization degree of PHB because of a reduction in the lamellar thickness of PHB, resulting in confined PHB molecules in the blends. Finally, the melting temperature $(\mathrm{Tm})$ did not change when $\mathrm{ChNCs}$ were added to the PHB-based formulations. Notably, however, some variations in the shape of the melting peak were observed, particularly in the second heating cycle. Neat PHB showed two distinct melting peaks: a lower peak at approximately $160^{\circ} \mathrm{C}$ and an upper peak at approximately $170^{\circ} \mathrm{C}$. The upper melting peak is dominant, suggesting that the PHB sample has a nonhomogeneous morphology with mostly stable crystals, but unstable crystals are also present and agrees with the results obtained by Owen et al. [54]. However, the nanocomposites showed only one melting peak at $170{ }^{\circ} \mathrm{C}$, with a shoulder at $160^{\circ} \mathrm{C}$, suggesting that a higher fraction of PHB crystals are present in their stable configuration, and a more homogeneous morphology is induced by the ChNCs.

Table 1. DSC results of the studied nanocomposites. Values for each cycle are reported.

\begin{tabular}{cccccccc}
\hline \multirow{2}{*}{ Materials } & \multicolumn{6}{c}{ Cooling } & \multicolumn{5}{c}{ 2nd Heating } \\
\cline { 2 - 8 } & $\mathbf{T}_{\mathbf{c}}\left[{ }^{\circ} \mathbf{C}\right]$ & $\Delta \mathbf{H}_{\mathbf{c}}[\mathbf{J} / \mathbf{g}]$ & $\mathbf{T c c}\left[{ }^{\circ} \mathbf{C}\right]$ & $\Delta \mathbf{H}_{\mathbf{c c}}[\mathbf{J} / \mathbf{g}]$ & $\mathbf{T}_{\mathbf{m}}\left[{ }^{\circ} \mathbf{C}\right]$ & $\Delta \mathbf{H}_{\mathbf{m}}[\mathbf{J} / \mathbf{g}]$ & $\mathbf{X}_{\mathbf{c}}[\%]$ \\
\hline Neat PHB & 66 & 58 & - & 0 & 170 & 88 & 60 \\
PHB/1ChNC & 54 & 36 & 42 & 8 & 170 & 82 & 50 \\
PHB/5ChNC & 49 & 29 & 41 & 10 & 170 & 79 & 49 \\
\hline
\end{tabular}
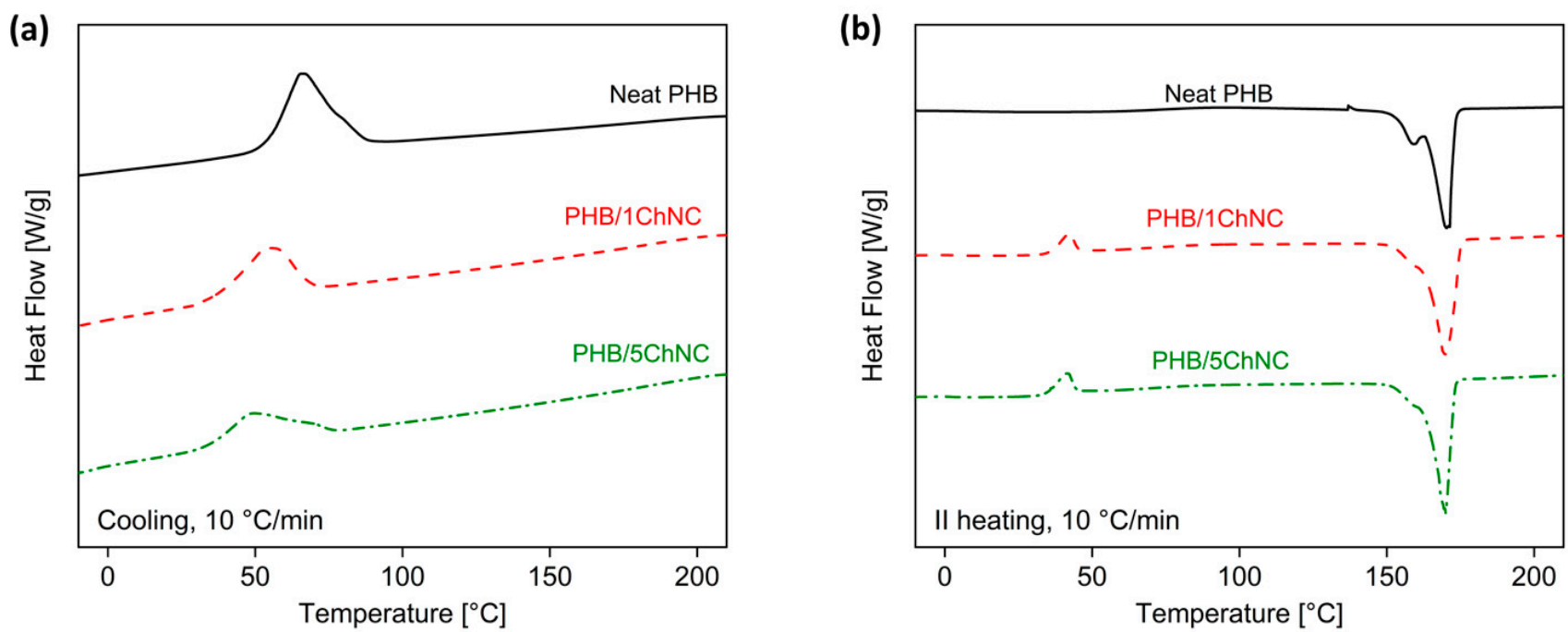

Figure 6. Thermal properties of neat PHB compared with the nanocomposites: (a) cooling cycle from 210 to $-10{ }^{\circ} \mathrm{C}$, (b) second heating cycle from -10 to $210{ }^{\circ} \mathrm{C}$.

Figure 7 shows the complex viscosity $\eta^{*}$ of neat PHB and its nanocomposites as a function of the oscillation frequency. PHB shows shear-thinning behavior, with the viscosity decreasing with increasing frequency. This behavior is more pronounced in the lowfrequency region. The addition of ChNCs increased the viscosity, and the nanocomposite with the highest ChNC content exhibited the highest viscosity. This viscosity trend was consistently observed in the entire studied frequency range. 


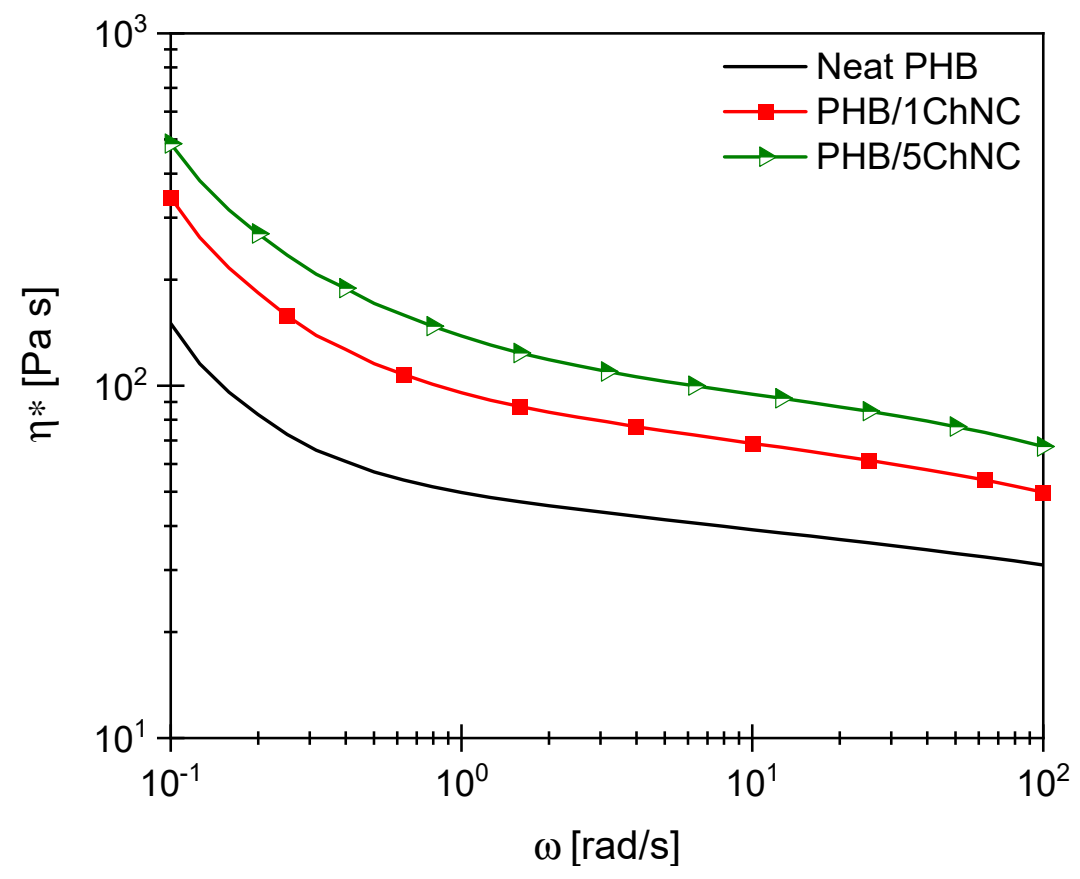

Figure 7. Rheology of the studied PHB-based nanocomposites.

Figure 8 shows representative stress-strain curves of neat PHB and its nanocomposites in the machine direction (MD) and transverse direction (TD), and the results are reported in Table 2. The graphs in Figure 8 show that the mechanical properties in MD are significantly higher than those in TD. This effect is evident even in the neat PHB. This is due to the calendering process, which is resulting in the alignment of the polymer at the molecular level and is previously reported for polymer and biopolymer calendered films [55]. Furthermore, the addition of ChNCs significantly enhances the mechanical strength of the PHB. A substantial increase in the tensile strength, from $24 \mathrm{MPa}$ for neat PHB to 27 $\mathrm{MPa}(1 \mathrm{wt} . \% \mathrm{ChNCs})$ to $33 \mathrm{MPa}(5 \mathrm{wt} . \% \mathrm{ChNCs})$, corresponding to an increase of $17 \%$ and $38 \%$, respectively, is seen in MD. The samples in TD exhibit a similar pattern and suggest an improvement in tensile strength due to the presence of $\mathrm{ChNCs}$, although the strength values remain lower than the MD one, this is explained with lack of orientation of the molecule chains in the transversal direction. The improved tensile strength is an indication of a good interface between PHB and the ChNCs. The addition of ChNCs does not significantly affect the tensile modulus in MD, while a slight decrease is seen in TD. All the materials displayed brittle behavior with a low elongation at break. Interestingly, the strain at the break did not decrease with the addition of agglomerated ChNCs, which is a common effect of good stress transfer [31,56,57].

Table 2. Tensile test results in both MD and TD for the studied nanocomposites and neat PHB.

\begin{tabular}{ccccccc}
\hline Materials & & $\begin{array}{c}\text { E-Modulus } \\
{[\mathrm{GPa}]}\end{array}$ & $\begin{array}{c}\boldsymbol{\sigma}_{\max } \\
{[\mathbf{M P a}]}\end{array}$ & $\begin{array}{c}\varepsilon \text { at } \boldsymbol{\sigma}_{\max } \\
{[\%]}\end{array}$ & $\begin{array}{c}\varepsilon_{\text {break }} \\
{[\%]}\end{array}$ & $\begin{array}{c}\text { Toughness } \\
{\left[\mathbf{M J} / \mathbf{m}^{3}\right]}\end{array}$ \\
\hline \multirow{2}{*}{$\mathrm{PHB}$} & MD & $2.7 \pm 0.2$ & $24 \pm 2$ & $1.1 \pm 0.1$ & $1.2 \pm 0.1$ & $0.13 \pm 0.0$ \\
& TD & $1.8 \pm 0.2$ & $14 \pm 0$ & $0.9 \pm 0.2$ & $1.0 \pm 0.2$ & $0.06 \pm 0.1$ \\
\hline \multirow{2}{*}{$\mathrm{PHB} / 1 \mathrm{ChNC}$} & MD & $2.7 \pm 0.1$ & $27 \pm 1$ & $1.3 \pm 0.1$ & $1.5 \pm 0.2$ & $0.18 \pm 0.1$ \\
& TD & $2.4 \pm 0.3$ & $22 \pm 0$ & $1.1 \pm 0.1$ & $1.1 \pm 0.1$ & $0.13 \pm 0.1$ \\
\hline \multirow{2}{*}{$\mathrm{PHB} / 5 \mathrm{ChNC}$} & MD & $2.8 \pm 0.1$ & $33 \pm 4$ & $1.6 \pm 0.4$ & $1.7 \pm 0.4$ & $0.22 \pm 0.0$ \\
& TD & $2.5 \pm 0.2$ & $21 \pm 0$ & $1.0 \pm 0.1$ & $1.0 \pm 0.1$ & $0.12 \pm 0.0$ \\
\hline
\end{tabular}




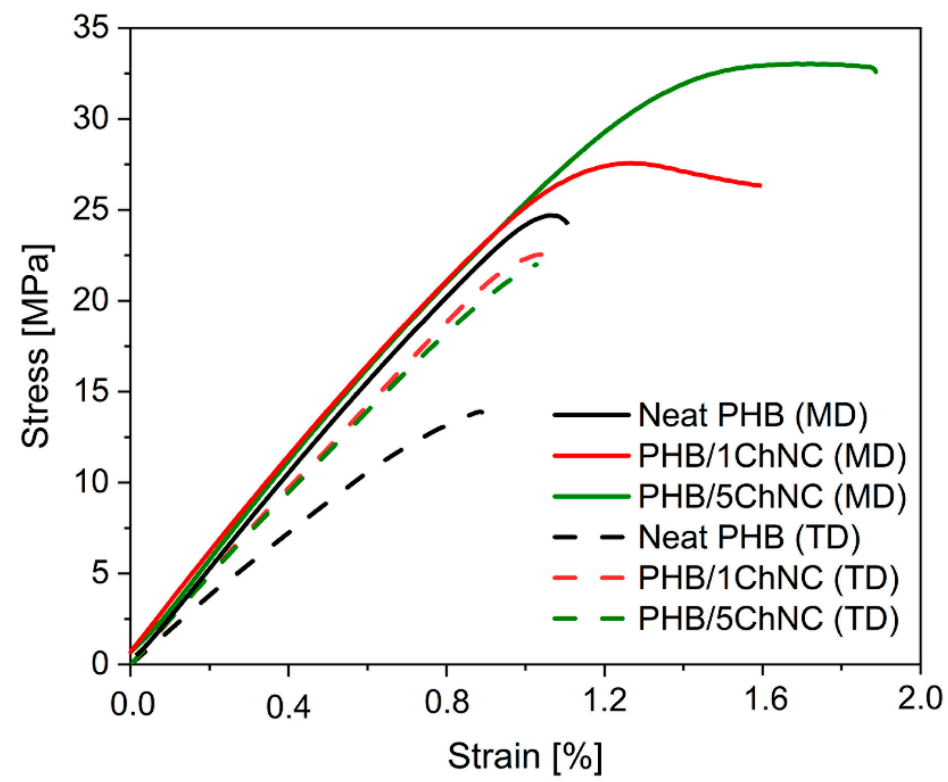

Figure 8. Tensile stress-strain curves of PHB and its nanocomposites with ChNCs in MD and TD directions.

Figure 9 shows the microstructures of PHB and its nanocomposite sheets. The neat PHB sheet in Figure 9a is homogeneous, whereas multiple particles are observed in both nanocomposites in Figure $9 \mathrm{~b}, \mathrm{c}$, and the number of particles increases with the $\mathrm{ChNC}$ concentration. The ChNC material structure is very similar (a flake-like structure), as previously reported by Herrera et al. [58]. Therefore, these particles are most likely ChNCs agglomerates that were not dispersed at the nanoscale.
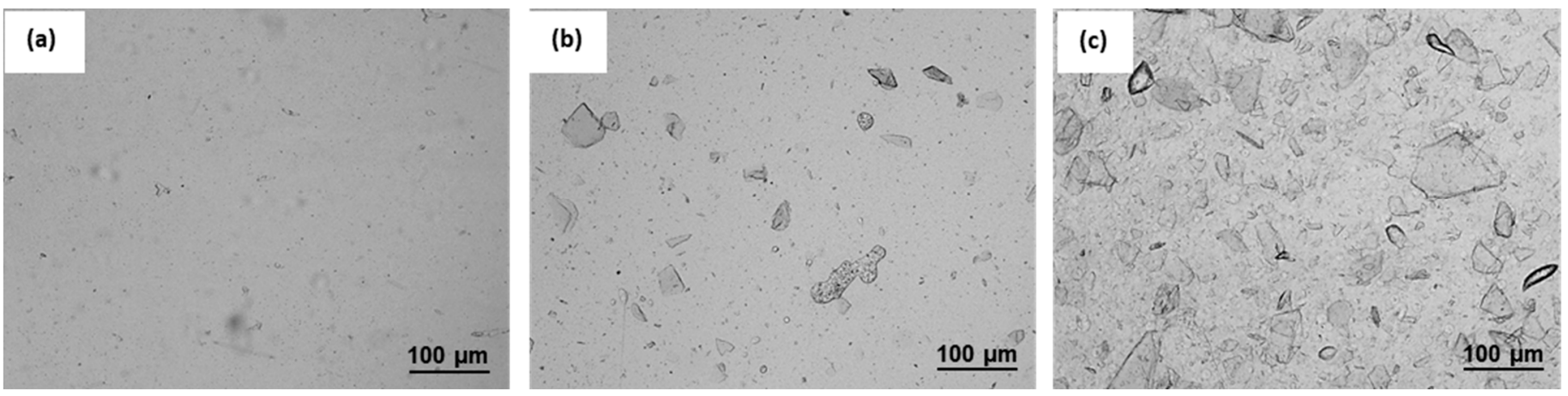

Figure 9. The OM images of cast-extruded (a) PHB, (b) PHB/1ChNC, and (c) PHB/5ChNC show an increasing number of $\mathrm{ChNC}$ particles in the $\mathrm{PHB}$ matrix with increasing $\mathrm{ChNC}$ content.

Figure 10 shows the fractured surfaces of neat PHB and its nanocomposites with 1 and $5 \mathrm{wt} . \% \mathrm{ChNC}$ contents. These micrographs indicate that all the samples underwent brittle fracture, which agrees with the results of mechanical testing. The fractured surface structure of the nanocomposites looks quite different from that of neat PHB (Figure 10a), and the difference is especially prominent for the nanocomposite with the lower $\mathrm{ChNCs}$ content (Figure 10b). However, both nanocomposites show micrometer-sized, layered, flake-like structures (Figure 10b,c). In addition, the nanocomposite with $5 \mathrm{wt} . \% \mathrm{ChNC}$ has several agglomerates that are larger than those in the nanocomposite with $1 \mathrm{wt} . \% \mathrm{ChNCs}$. These results agree with the OM analysis of the sheets. The formation of these ChNC agglomerates can be attributed to the freeze-drying step before the compounding process. The ChNCs form hydrogen bonds, resulting in an irreversible agglomeration that cannot be redispersed in the PHB matrix during the compounding process. 

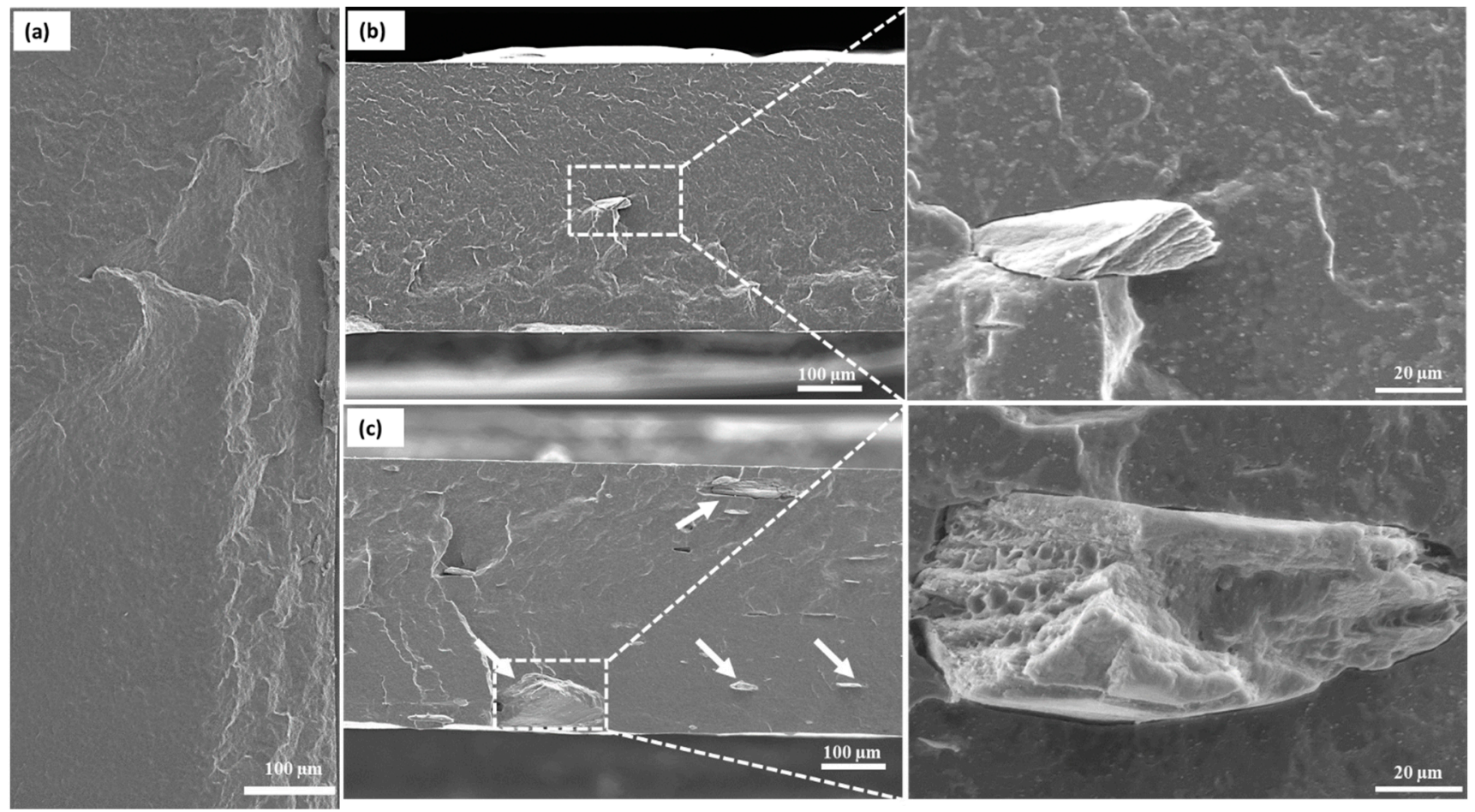

Figure 10. SEM images of the cryo-fractured surfaces of (a) PHB, (b) PHB/1ChNC, and (c) $\mathrm{PHB} / 5 \mathrm{ChNC}$.

\section{Conclusions}

This study reports the properties of PHB biopolymer reinforced with ChNCs. The PHB and ChNCs used in this study were produced at a large scale from biomass and chitin powder, respectively. The materials (neat PHB and nanocomposites) were prepared by melt extrusion, and the materials for testing were prepared by calendering.

We successfully demonstrated the large-scale production of ChNCs using $\mathrm{H}_{2} \mathrm{SO}_{4}$ acid hydrolysis. However, the freeze-drying step to facilitate the transport of large ChNCs resulted in irreversible agglomeration, as shown in the OM images.

Polarized optical microscopy showed that pure PHB had a higher crystallization rate and formed larger spherulites than the nanocomposites. The DSC results showed that the presence of ChNCs resulted in a lower degree of crystallinity and a slower crystallization rate. However, some variations in the shape of the melting peak were observed for the nanocomposites, presenting only one melting peak at $170{ }^{\circ} \mathrm{C}$ with a shoulder at $160{ }^{\circ} \mathrm{C}$. It is assumed that the presence of $\mathrm{ChNCs}$ induced the formation of a higher fraction of more stable PHB crystals and a more homogeneous nanocomposite morphology.

The addition of ChNCs significantly enhanced the mechanical strength of the nanocomposites in both the machine (MD) and transversal directions (TD). The samples in the MD showed significantly higher mechanical properties than those in the TD direction, owing to the partial orientation during the calendering process.

Morphological studies performed by OM and SEM showed that despite the presence of a few larger micro-sized agglomerates of $\mathrm{ChNC}$ due to their dry feeding during the melt mixing process, a uniform distribution was obtained.

This study has demonstrated that adding a small amount of bio-based biodegradable nanoparticles, such as ChNCs, has a toughening effect on PHB, which is well known to exhibit brittle behavior and can therefore promote the use of this material even in applications where good mechanical properties are required. It is worth noting that these results were obtained by mixing ChNCs in a polymer matrix via melt extrusion in a twinscrew extruder, which is a typical process commercially used with thermoplastics; therefore, these results can be easily scaled up to the industrial level. 


\begin{abstract}
Supplementary Materials: The following supporting information can be downloaded at: https: / / www.mdpi.com/article/10.3390/polym14030562/s1, Figure S1: Flow diagram of the fermentation process for PHB production; Figure S2: Time course of (a) CDW (g/L) accumulation in a $1.5 \mathrm{~m}^{3}$ reactor and (b) PHB (g/L) production; Figure S3: Processing scheme of the large-scale ChNCs production process; Figure S4: AFM height images of the produced ChNCs; Figure S5: XRD analysis of raw chitin powder.
\end{abstract}

Author Contributions: Conceptualization, M.Z. and M.M.; methodology, M.Z., M.L.M., R.N., L.D.B. and M.K.P.; validation, M.Z. and M.M.; formal analysis, M.Z., M.L.M., L.D.B., R.N. and M.K.P.; resources, M.Z.; data curation, M.Z., M.M. and M.K.P.; writing-original draft preparation, M.Z., M.M., R.N., L.D.B. and M.K.P.; writing—review \& editing, M.Z., R.N., M.K.P., K.O. and M.M.; visualization, M.Z. and M.M.; supervision, K.O., R.N. and M.M.; project administration, M.Z., K.O. and R.N. All authors have read and agreed to the published version of the manuscript.

Funding: This research was funded by the European Community's Horizon 2020 Program, Grant Agreement No. 792261 (Newpack BBI Horizon 2020 EU project), Authors are grateful for financial support from the Bio4Energy Swedish Strategic Research Program.

Institutional Review Board Statement: Not applicable.

Informed Consent Statement: Not applicable.

Data Availability Statement: Data is available on request.

Conflicts of Interest: The authors declare no conflict of interest.

\title{
References
}

1. Ollier, R.P.; D'Amico, D.A.; Schroeder, W.F.; Cyras, V.P.; Alvarez, V.A. Effect of clay treatment on the thermal degradation of PHB based nanocomposites. Appl. Clay Sci. 2018, 163, 146-152. [CrossRef]

2. Hablot, E.; Bordes, P.; Pollet, E.; Avérous, L. Thermal and thermo-mechanical degradation of poly(3-hydroxybutyrate)-based multiphase systems. Polym. Degrad. Stab. 2008, 93, 413-421. [CrossRef]

3. Saad, G.R.; Salama, H.E.; Mohamed, N.A. Crystallization and thermal properties of biodegradable polyurethanes based on poly[(R)-3-hydroxybutyrate] and their composites with chitin whiskers. J. Appl. Polym. Sci. 2014, 131, 9395-9407. [CrossRef]

4. Philip, S.; Keshavarz, T.; Roy, I. Polyhydroxyalkanoates: Biodegradable polymers with a range of applications. J. Chem. Technol. Biotechnol. 2007, 82, 233-247. [CrossRef]

5. Ojumu, T.V.; Yu, J.; Solomon, B.O. Production of Polyhydroxyalkanoates, a bacterial biodegradable polymer. Afr. J. Biotechnol. 2004, 3, 18-24. [CrossRef]

6. $\quad$ Pietrini, M.; Roes, L.; Patel, M.K.; Chiellini, E. Comparative life cycle studies on poly(3-hydroxybutyrate)-based composites as potential replacement for conventional petrochemical plastics. Biomacromolecules 2007, 8, 2210-2218. [CrossRef]

7. Hazer, D.B.; Kiliçay, E.; Hazer, B. Poly (3-hydroxyalkanoate)s: Diversification and Biomedical Applications. A State of the Art Review. Mater. Sci. Eng. C 2012, 32,637-647. [CrossRef]

8. Chen, G.-Q. (Ed.) Plastics Completely Synthesized by Bacteria: Polyhydroxyalkanoates. In Plastics from Bacteria: Natural Functions and Applications. Microbiology Monographs; Springer: New York, NY, USA, 2010; Volume 14, pp. 17-37. [CrossRef]

9. Khasanah, R.K.R.; Sato, H.; Takahashi, I.; Ozaki, Y. Intermolecular hydrogen bondings in the poly(3-hydroxybutyrate) and chitin blends: Their effects on the crystallization behavior and crystal structure of poly(3-hydroxybutyrate). Polymer 2015, 75, 141-150. [CrossRef]

10. Qian, J.; Zhu, L.; Zhang, J.; Whitehouse, R.S. Comparison of different nucleating agents on crystallization of poly(3hydroxybutyrate-co-3-hydroxyvalerates). J. Polym. Sci. B Polym. Phys. 2007, 45, 1564-1577. [CrossRef]

11. Zhao, Q.; Cheng, G. Biodegradable PHB/PEG Derivatives and their Degradation Behavior. In New Frontiers in Polymer Research; Bregg, R.K., Ed.; Nova Science Publishers, Inc.: New York, NY, USA, 2006; Volume 5, pp. 99-124.

12. Sudesh, K.; Abe, H.; Doi, Y. Synthesis, structure, and properties of polyhydroxyalkanoates: Biological polyester. Prog. Polym. Sci. 2000, 25, 1503-1555. [CrossRef]

13. Satkowski, M.M.; Melik, D.H.; Autran, J.-P.; Green, P.R.; Noda, I.; Schechtman, L.A. Physical and processing properties of polyhydroxyalkanoate (PHA) copolymers. In Biopolymers; Steinbüchel, A., Doi, Y., Eds.; Wiley-VCH: Weinheim, Germany, 2001; Volume 3b, pp. 231-263. [CrossRef]

14. Jaques, N.G.; dos Santos Silva, I.D.; da Cruz Barbosa Neto, M.; Ries, A.; Canedo, E.L.; Wellen, R.M.R. Effect of heat cycling on melting and crystallization of $\mathrm{PHB} / \mathrm{TiO}_{2}$ compounds. Polimeros 2018, 28, 161-168. [CrossRef]

15. Marchessault, R.H.; Okamura, K.; Su, C.J. Physical Properties of Poly( $\beta$-hydroxy butyrate). II. Conformational Aspects in Solution. Macromolecules 1970, 3, 735-740. [CrossRef]

16. De Koning, G.J.M.; Lemstra, P.J. Crystallization phenomena in bacterial poly[(R)-3-hydroxybutyrate]: 2 . Embrittlement and rejuvenation. Polymer 1993, 34, 4089-4094. [CrossRef] 
17. De Koning, G.J. Embrittlement and Rejuvenation of Bacterial Poly[(R)-3-hydroxybutyrate]. In Polymers from Agricultural Coproducts; Fishman, M.L., Friedman, R.B., Huang, S.J., Eds.; American Chemical Society: Washington, DC, USA, 1994; Chapter 13; Volume 575, pp. 188-201. [CrossRef]

18. Yeo, J.C.C.; Muiruri, J.K.; Thitsartarn, W.; Li, Z.; He, C. Recent advances in the development of biodegradable PHB-based toughening materials: Approaches, advantages, and applications. Mater. Sci. Eng. C Mater. Biol. Appl. 2018, 92, $1092-1116$. [CrossRef] [PubMed]

19. Gerard, T.; Budtova, T.; Podshivalov, A.; Bronnikov, S. Polylactide/poly(hydroxybutyrate-co-hydroxyvalerate) blends: Morphology and mechanical properties. eXPRESS Polym. Lett. 2014, 8, 609-617. [CrossRef]

20. Perret, E.; Reifler, F.A.; Gooneie, A.; Chen, K.; Selli, F.; Hufenus, R. Structural response of melt-spun poly(3-hydroxybutyrate) fibers to stress and temperature. Polymer 2020, 197, 122503. [CrossRef]

21. Pandey, J.K.; Kumar, A.P.; Misra, M.; Mohanty, A.K.; Drzal, L.T.; Palsingh, R. Recent advances in biodegradable nanocomposites. J. Nanosci. Nanotechnol. 2005, 5, 497-526. [CrossRef]

22. Chivrac, F.; Kadlecová, Z.; Pollet, E.; Avérous, L. Aromatic copolyester-based nano-biocomposites: Elaboration, structural characterization, and properties. J. Polym. Environ. 2006, 14, 393-401. [CrossRef]

23. Chen, G.; Hao, G.; Guo, T.; Song, M.; Zhang, B. Structure and mechanical properties of poly (3-hydroxybutyrate-co-3hydroxyvalerate)(PHBV)/clay nanocompo-sites. J. Mater. Sci. Lett. 2002, 21, 1587-1589. [CrossRef]

24. Chen, G.; Hao, G.; Guo, T.; Song, M.; Zhang, B. Crystallization kinetics of poly (3-hydroxybutyrate-co-3-hydroxyvalerate)/clay nanocomposites. J. Appl. Polym. Sci. 2004, 93, 655-661. [CrossRef]

25. Lim, S.T.; Hyun, Y.H.; Lee, C.H.; Choi, H.J. Preparation, and characterization of microbial biodegradable poly (3hydroxybutyrate)/organoclay nanocomposite. J. Mater. Sci. Lett. 2003, 22, 299-302. [CrossRef]

26. Choi, W.M.; Kim, T.W.; Park, O.O.; Chang, Y.K.; Lee, J.W. Preparation and characterization of poly(hydroxybutyrate-cohydroxyvalerate)-organoclay nanocomposites. J. Appl. Polym. Sci. 2003, 90, 525-529. [CrossRef]

27. Wang, S.; Song, C.; Chen, G.; Guo, T.; Liu, J.; Zhang, B.; Takeuchi, S. Characteristics, and biodegradation properties of poly (3-hydroxybutyrate-co-3-hy-droxyvalerate)/organophilic montmorillonite (PHBV/OMMT) nanocomposite. Polym. Degrad. Stab. 2005, 87, 69-76. [CrossRef]

28. Malucelli, G. High barrier composite materials based on renewable sources for food packaging applications. In Food Packaging; Grumezescu, A.M., Ed.; Elsevier Inc.: Amsterdam, The Netherlands, 2017; Volume 2, pp. 45-78. [CrossRef]

29. Duan, B.; Huang, Y.; Lu, A.; Zhang, L.N. Recent advances in chitin-based materials con-structed via physical methods. Prog. Polym. Sci. 2018, 82, 1-33. [CrossRef]

30. Shamshina, J.L.; Berton, P.; Rogers, R.D. Advances in functional chitin materials: A review. ACS Sustain. Chem. Eng. 2019, 7, 6444-6457. [CrossRef]

31. Li, J.; Wang, Y.; Wang, Z.; Wang, J.; Wu, D. Surface chain engineering of chitin nanocrystals towards tailoring the nucleating capacities for poly( $\beta$-hydroxybutyrate). Int. J. Biol. Macromol. 2021, 166, 967-976. [CrossRef]

32. Li, S.C.Y.; Sun, Y.C.; Guan, Q.; Naguib, H. Effects of chitin nanowhiskers on the thermal, barrier, mechanical, and rheological properties of polypropylene nanocomposites. RSC Adv. 2016, 6, 72086-72095. [CrossRef]

33. Rinaudo, M. Chitin and chitosan: Properties and applications. Prog. Polym. Sci. 2006, 31, 603-632. [CrossRef]

34. Marchessault, R.H.; Morehead, F.F.; Walter, N.M. Liquid crystal systems from fibrillar polysaccharides. Nature 1959, 184, 632-633. [CrossRef]

35. Zeng, J.B.; He, Y.S.; Li, S.L.; Wang, Y.Z. Chitin whiskers: An overview. Biomacromolecules 2012, 13, 1-11. [CrossRef]

36. Paillet, M.; Dufresne, A. Chitin whisker reinforced thermoplastic nanocomposites. Macromolecules 2001, 34, 6527-6530. [CrossRef]

37. Gopalan Nair, K.; Dufresne, A. Crab shell chitin whisker reinforced natural rubber nanocomposites. 1. Processing and swelling behavior. Biomacromolecules 2003, 4, 657-665. [CrossRef] [PubMed]

38. Pereira, A.G.B.; Muniz, E.C.; Hsieh, Y.L. Chitosan-sheath and chitincore nanowhiskers. Carbohydr. Polym. 2014, 107, 158-166. [CrossRef] [PubMed]

39. Patel, M.; Schwendemann, D.; Spigno, G.; Geng, S.; Berglund, L.; Oksman, K. Functional nanocomposite films of poly(Lactic acid) with well-dispersed chitin nanocrystals achieved using a dispersing agent and liquid-assisted extrusion process. Molecules 2021, 26, 4557. [CrossRef]

40. Salaberria, A.M.; Labidi, J.; Fernandes, S.C.M. Different routes to turn chitin into stunning nano-objects. Eur. Polym. J. 2015, 68, 503-515. [CrossRef]

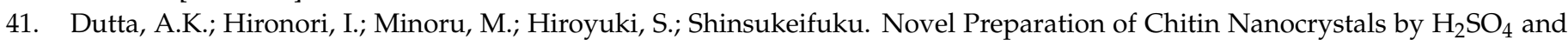
$\mathrm{H}_{3} \mathrm{PO}_{4}$ Hydrolysis Followed by High-Pressure Water Jet Treatments. J. Chitin. Chitosan. Sci. 2014, 2, 179-184. [CrossRef]

42. Oun, A.A.; Rhim, J.W. Effect of isolation methods of chitin nanocrystals on the properties of chitin-silver hybrid nanoparticles. Carbohydr. Polym. 2018, 197, 349-358. [CrossRef]

43. Scaffaro, R.; Botta, L.; Lopresti, F.; Maio, A.; Sutera, F. Polysaccharide nanocrystals as fillers for PLA based nanocomposites. Cellulose 2017, 24, 447-478. [CrossRef]

44. Ravi Kumar, M.N.V. A review of chitin and chitosan applications. React. Funct. Polym. 2000, 46, 1-27. [CrossRef]

45. Singh, S.; Maspoch, M.L.; Oksman, K. Crystallization of triethyl-citrate-plasticized poly(lactic acid) induced by chitin nanocrystals. J. Appl. Polym. Sci. 2019, 136, 47936. [CrossRef] 
46. Visakh, P.M.; Monti, M.; Puglia, D.; Rallini, M.; Santulli, C.; Sarasini, F.; Thomas, S.; Kenny, J.M. Mechanical and thermal properties of crab chitin reinforced carboxylated SBR composites. Express Polym. Lett. 2012, 6, 396-409. [CrossRef]

47. Singh, S.; Patel, M.; Schwendemann, D.; Zaccone, M.; Geng, S.Y.; Maspoch, M.L.; Oksman, K. Effect of chitin nanocrystals on crystallization and properties of poly(lactic acid)-based nanocomposites. Polymers 2020, 12, 726. [CrossRef] [PubMed]

48. Kim, B.S.; Lee, S.C.; Lee, S.Y.; Chang, H.N.; Chang, Y.K.; Woo, S.I. Production of poly(3-hydroxybutyric acid) by fed-batch culture of Alcaligenes eutrophus with glucose concentration control. Biotechnol. Bioeng. 1994, 43, 892-898. [CrossRef] [PubMed]

49. Barham, P.J.; Keller, A.E.; Otun, L.; Holmes, P.A. Crystallization and morphology of a bacterial thermoplastic: Poly-3hydroxybutyrate. J. Mat. Sci. 1984, 19, 2781-2794. [CrossRef]

50. Meng, D.; Xie, J.; Waterhouse, G.I.N.; Zhang, K.; Zhao, Q.; Wang, S.; Qiu, S.; Chen, K.; Li, J.; Ma, C.; et al. Biodegradable Poly(butylene adipate-co-terephthalate) composites reinforced with bio-based nanochitin: Preparation, enhanced mechanical and thermal properties. J. Appl. Polym. Sci. 2019, 137, 48485. [CrossRef]

51. Roman, M.; Winter, W.T. Effect of sulfate groups from sulfuric acid hydrolysis on the thermal degradation behavior of bacterial cellulose. Biomacromolecules 2004, 5, 1671-1677. [CrossRef]

52. Kai, W.; He, Y.; Inoue, Y. Fast crystallization of poly(3-hydroxybutyrate) and poly(3-hydroxybutyrate-co-3-hydroxyvalerate) with talc and boron nitride as nucleating agents. Polym. Int. 2005, 54, 780-789. [CrossRef]

53. Ikejima, T.; Yagi, K.; Inoue, Y. Thermal properties and crystallization behavior of poly (3-hydroxybutyric acid) in blends with chitin and chitosan. Macromol. Chem. Phys. 1999, 200, 413-421. [CrossRef]

54. Owen, A.J.; Krabi, J.H.; Divjakovi, V. Crystallization and melting behaviour of PHB and PHB/HV copolymer. Polymer 1992, 33, 1563-1567. [CrossRef]

55. La Mantia, F.P.; Ceraulo, M.; Testa, P.; Morreale, M. Biodegradable Polymers for the Production of Nets for Agricultural Product Packaging. Materials 2021, 14, 323. [CrossRef]

56. Herrera, N.; Roch, H.; Salaberria, A.M.; Pino-Orellana, M.A.; Labidi, J.; Fernandes, S.C.M.; Radic, D.; Leiva, A.; Oksman, K. Functionalized blown films of plasticized polylactic acid/chitin nanocomposite: Preparation and characterization. Mater. Des. 2016, 92, 846-852. [CrossRef]

57. Coltelli, M.B.; Cinelli, P.; Gigante, V.; Aliotta, L.; Morganti, P.; Panariello, L.; Lazzeri, A. Chitin nanofibrils in poly(lactic acid) (PLA) nanocomposites: Dispersion and thermo-mechanical properties. Int. J. Mol. Sci. 2019, 20, 504. [CrossRef] [PubMed]

58. Herrera, N.; Salaberria, A.M.; Mathew, A.P.; Oksman, K. Plasticized polylactic acid nanocomposite films with cellulose and chitin nanocrystals prepared using extrusion and compression molding with two cooling rates: Effects on mechanical, thermal and optical properties. Compos. Part A 2019, 83, 89-97. [CrossRef] 